\title{
Microbiomes associated with cultures of Gambierdiscus australes and Ostreopsis cf. ovata, two epibenthic dinoflagellates from the NE Atlantic Ocean (Las Palmas, Gran Canaria)
}

\author{
Renata Denaro $^{1}$ ( ) | Francesca Crisafi ${ }^{3}$ ( ) | Francesco Smedile $^{3}$ | Vittorio Soprano ${ }^{4}$ | \\ Rachele Rossi $^{4}$ | Adriana Zingone ${ }^{6}$ | Felix Acosta ${ }^{5}$ | Maria Grazia Giacobbe ${ }^{2}$
}

${ }^{1}$ National Research Council, Water Research Institute (IRSA-CNR), Rome, Italy

${ }^{2}$ National Research Council, Institute of Marine Biological Resources and Biotechnologies. (CNR IRBIM), Messina, Italy

${ }^{3}$ National Research Council, Institute of Polar Sciences (ISP - CNR), Messina, Italy ${ }^{4}$ Istituto Zooprofilattico Sperimentale del Mezzogiorno, Portici, Italy

${ }^{5}$ Grupo de Investigación en Acuicultura. IU-Ecoaqua, Universidad de Las Palmas de Gran Canaria, Las Palmas de Gran Canaria, Spain

${ }^{6}$ Stazione Zoologica Anton Dohrn, Napoli, Italy

\section{Correspondence}

Renata Denaro, Water Research Institute (IRSA-CNR), Via Salaria km 29.300, Monterotondo, 00015 RM, Italy. Email: denaro@irsa.cnr.it

\begin{abstract}
Our study focuses on bacterial communities associated with two benthic, epiphytic dinoflagellates, Gambierdiscus australes and Ostreopsis cf. ovata, isolated from coastal waters of Las Palmas, Gran Canaria, and grown in clonal cultures. The goal was to characterize the stable bacterial consortia found within the phycosphere of each dinoflagellate species and establish into which functional group they fell. High-throughput sequencing (HTS) results highlighted a higher bacterial diversity in O. ovata compared with $G$. australes. Alphaproteobacteria dominated in both dinoflagellates with Marivita and Labrenzia as the most represented OTUs in Ostreopsis and Gambierdiscus, respectively, and Thalassospira and Oceanicaulis well represented in both species. Based on SIMPER analyses, Labrenzia and the Phycispherales SM1A02, dominant in Gambierdiscus and Ostreopsis, respectively, accounted for the most significant difference between the two microbiomes. The microbiomes described here differed from those described for the same dinoflagellate species in other studies, which could depend on differences in environmental conditions, macroalgal substrate, and/or growth stage or bloom phase of the microalgal hosts. The distinct bacterial communities associated with the two potentially toxic dinoflagellates, isolated from the same site and sampling event and cultivated under the same conditions, suggest different modalities of interaction and interexchange between bacteria and their hosts.
\end{abstract}

KEYWORDS

16S rDNA bacterial diversity, algae, dinoflagellates, microbial structure, phycosphere

\section{1 | INTRODUCTION}

In aquatic environments, bacteria have been recognized as potential regulators of the algal metabolism and behavior, including growth, bloom initiation, maintenance, and decline (Amin et al., 2015; Gonzalez \& Bashan, 2000; Kim et al., 2014; Seyedsayamdost et al., 2011). Although algal-bacterial interactions are viewed as discrete events depending upon environmental factors, many studies report the recurrent co-presence of algae and bacteria in the same microenvironments (e.g., phycosphere, corals, and lichens) where complex mutualistic (Croft et al., 2005), commensal, competitive (Bratbak \& Thingstad, 1985), and parasitic relationships (Sachs \& Wilcox, 2006) can occur. The interactions between bacteria and algae are essential in regulating algal accumulation and degradation of organic matter 


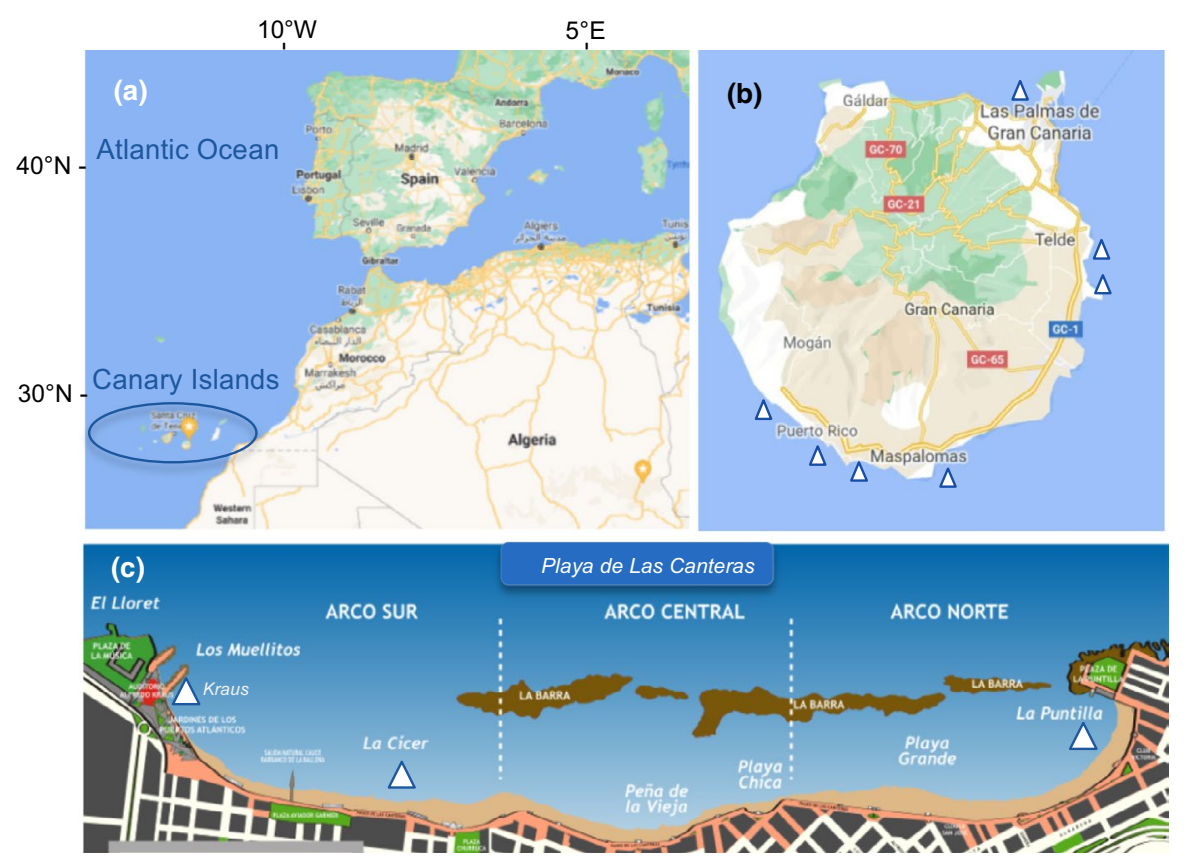

FIGURE 1 Location of the Canary Islands in the Atlantic Ocean (a) and sampling stations along the Gran Canaria coast (b). Details are provided on the northern area of sampling, Playa di Las Canteras in Las Palmas (c)

(Cole et al., 1988; Fuentes et al., 2016). Moreover, bacterial communities hosted by dinoflagellates have been associated with their growth through the production of vitamins, iron chelators (siderophores), and cytokinins (Jasti et al., 2005).

Bacteria associated with toxic algae have earned an increasing interest due to their possible influence on the algal toxicity expression. Marine biotoxins produced by microalgae, including dinoflagellates, are known to accumulate through the food chain, with a heavy impact on human health, marine organisms, and aquaculture activity. The phylum Dinophyta includes many species able to produce different toxins, agents of human illnesses. Several planktonic species are responsible for syndromes such as paralytic shellfish poisoning (PSP), neurotoxic shellfish poisoning (NSP), and diarrhetic shellfish poisoning (DSP). Among benthic dinoflagellates, Ostreopsis spp., produce isobaric palytoxin (PLTX) and ovatoxins (OVTXs) which are associated with human respiratory illness by exposure to toxic aerosol (García-Altares et al., 2014; Tibiriçá et al., 2019), whereas Gambierdiscus spp. and Fukuyoa spp. are responsible for ciguatera fish poisoning (CFP) (Murray et al., 2020; Wang, 2008). The last disorder is a serious problem affecting public health and fishing industries in tropical and sub-tropical regions, and an emerging risk in temperate areas, such as European seas (Aligizaki et al., 2008; Bravo et al., 2015; Kaufmann \& Böhm-Beck, 2013; Laza-Martínez et al., 2016; Zingone et al., 2021). In the last decade, ciguatera outbreaks took place in the Canaries and affected $\approx 100$ people following the consumption of local fish (Bravo et al., 2015). In autumn 2016, a bloom of Gambierdiscus spp. dominated by G. caribaeus was observed in the protected marine reserve El Hierro, the smallest Canarian island, whereas ciguatoxic fish species (up to 62.5\%) were found in the area in December of the same year (Acosta et al., 2018).

Interestingly, bacterial communities associated with toxic dinoflagellates seem to have a function on the regulation of algal toxin production (Orr et al., 2013). For instance, a threshold number or critical consortium of Proteobacteria are needed to promote PSP-toxin production by Gymnodinium catenatum, possibly through the supply of sufficient amounts of cofactors or precursors needed in the process (Green et al., 2004). In cultures of Ostreopsis and Gambierdiscus, bacterial diversity patterns on cell surfaces and in the associated extracellular matrices have been reported to vary with growth phase (Tosteson et al., 1989) whereas in Ostreopsis, the degree of toxicity has also been attributed to the composition of the bacterial assemblage (Pérez-Guzmán et al., 2008). Recent co-culturing experiments have highlighted how associated bacteria can influence both growth and toxin production in three Pacific Gambierdiscus strains (Wang et al., 2018). Bacterial diversity also varies in Ostreopsis cf. ovata between different phases of the blooms and over the course of growth cycle (Guidi et al., 2018; Vanucci et al., 2016). Nevertheless, the kind of physiological interaction in dinoflagellates-bacteria associations, as well as the specificity of the associations and the role of environmental conditions, is still unclear.

In this study, we investigated the bacterial microbiomes associated with two potentially toxic, epibenthic dinoflagellates, Gambierdiscus australes (GA) and Ostreopsis cf. ovata (OO), isolated from the Canary Islands (NE Atlantic Ocean) and maintained in culture under the same conditions. Specifically, one GA and one $\mathrm{OO}$ isolates obtained from macrophyte hosts collected simultaneously at the same location were cultured under the same conditions and their microbiomes were analyzed by $16 \mathrm{~S}$ rDNA high-throughput sequencing (HTS). We aimed at comparing the microbiome composition between the two species and, through a literature search, assessing whether the bacterial phycosphere composition of those isolates was unique or overlapped with that observed in the same species from elsewhere and in other dinoflagellate species. 


\section{2 | MATERIAL AND METHODS}

\section{1 | Sampling and dinoflagellate culturing}

Samples were collected in the framework of the EU project MIMAR (INTERREG MAC 2014-2020), aimed at the monitoring, control, and mitigation of changes in the marine ecosystems within the Macaronesian region. The Canaries are the largest and most easterly archipelago of this region, close to the African coasts, and are characterized by volcanic origin, contrasting landscapes and gentle climate. The sampling was conducted in Gran Canaria, which is subject to the influence of trade winds tempering the heat along the coasts during summer; these winds blow more intensely in the afternoon, when they are often moderate or even quite strong.

The cultures of the two potentially toxic, epibenthic dinoflagellates (Gambierdiscus and Ostreopsis species) were obtained from seaweed samples including more than one macroalgal species, collected in September 2015 at two coastal sites of Playa de Las Canteras (Las Palmas, Gran Canaria): Station 1, close to the Alfredo Kraus Conference Center (28 $07^{\prime} 51.6^{\prime \prime} \mathrm{N}, 15^{\circ} 26^{\prime} 49.7^{\prime \prime} \mathrm{W}$ ) and Station 2, at

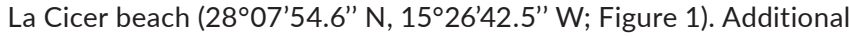
macroalgal samples were collected in September and October 2016, that is, in the months of reported Gambierdiscus occurrence (Tudò et al., 2020), at the two stations and at another station of the same beach, La Puntilla, as well as in other localities along the Gran Canaria coast: Playa Ojos de Garza, Melenara, Maspalomas beach, Playa de Puerto Rico, Arguineguín, and Playa de Mogán. At all stations, at a depth of about $0.5-1 \mathrm{~m}$, portions of seaweed thalli of 10 to $15 \mathrm{~g}$ fresh weight were collected with the surrounding water in 250 $\mathrm{ml}$ plastic bottles that were capped under water, according to the European protocol for Ostreopsis sampling (ENPI, M3_HABs, 2015). Sampling bottles were shaken for a few seconds, and macrophytes were rinsed several times with seawater to dislodge epiphytic cells. For each sample, all the seawater resulting from these operations was passed through a $20 \mu \mathrm{m}$-meshed filter to concentrate epiphytic cells. The concentrated material was stored in 50-ml tubes. Subsamples were fixed with Lugol's solution for cell counts, which was performed following the Uthermöhl method (1958) or using a Sedgewick Rafter chamber, depending on cell density. Unfixed samples were kept within steel thermos at $22-24^{\circ} \mathrm{C}$, according to the water temperature of the sampling site, and brought to CNR IRBIM laboratory in Messina (Italy) in $48 \mathrm{~h}$. There, the samples were observed using an inverted microscope (Axiovert 200 Zeiss), under which individual cells of Gambierdiscus or Ostreopsis were isolated with a micropipette, washed in sterile medium droplets several times, and finally placed in sterile polystyrene 24 -well culture plates kept under the following conditions: $24 \pm 1^{\circ} \mathrm{C}$, irradiance $60-80$ $\mu$ mole photons $\mathrm{m}^{-2} \mathrm{sec}^{-1}$, and light:dark period 14:10 h. Isolates were then transferred into 6-well culture plates and finally, one month after sampling, to $50 \mathrm{ml}$ culture bottles. Growth media used were K2 Keller or F4 Guillard in sterile seawater diluted at 32 ppt. All cultures were handled aseptically to prevent bacterial contamination and cross-contamination among cultures.
For morphological analyses, culture samples were stained with Calcofluor White M2R according to Fritz and Triemer (1985), which allows to observe the thecal plate pattern.

\subsection{DNA extraction and molecular characterization of dinoflagellates}

For definitive species identification, culture samples were collected after 15-20 days of growth for 18S-molecular analyses and processed as reported below. Approximately $10 \mathrm{ml}$ of each exponentially growing cultures of the two strains (CNR GA-LP and CNR OO-LP B1) was harvested by centrifugation (4000 rpm, $5 \mathrm{~min}$ ). Total genomic DNA was extracted using DNeasy Plant Kit (Qiagen), according to Penna and Magnani (1999) and the manufacturer's instructions. The extracted genomic DNA was used as template for PCR amplification of $18 \mathrm{~S}$ rDNA region using the NS1 and NS8 universal primers (White et al., 1990). The PCR was performed in a final reaction volume of $50 \mu$ l containing $2.5 \mu$ l of $1 X$ solution Q (Qiagen), $5 \mu$ of $1 \times$ Qiagen reaction buffer, $1 \mu$ l of each forward and reverse primer (10 $\mu \mathrm{M}$ stock), $1 \mu \mathrm{l}$ of dNTPs (10 $\mu \mathrm{M}$ stock) (Gibco, Invitrogen Co), 50 ng of DNA, 2.0 U of Qiagen Taq Polymerase (Qiagen), and nuclease-free water up to $50 \mu \mathrm{l}$. The PCR amplification was performed in GeneAmp 5700 (PE Applied Biosystems) using the following profile: 3 min hot-start at $95^{\circ} \mathrm{C} ; 30 \mathrm{cycles}$ at $1 \mathrm{~min} 94^{\circ} \mathrm{C}, 1 \mathrm{~min} 50^{\circ} \mathrm{C}, 2 \min 72^{\circ} \mathrm{C}$, and a final 10 -min extension at $72{ }^{\circ} \mathrm{C}$. PCR products were analyzed by horizontal $1 \%(\mathrm{w} / \mathrm{v})$ agarose gel electrophoresis $(100 \mathrm{~V}, 1 \mathrm{~h})$ in TAE 1X (Tris $0.04 \mathrm{M}$, EDTA $0.001 \mathrm{M}, \mathrm{pH}$ 8) electrophoresis buffer, to which $1 \mu \mathrm{l}(10000 \mathrm{x})$ of SYBR Safe (Invitrogen) was added. A $1 \mathrm{~kb}$ DNA ladder (Bio-Rad) was included as a molecular weight marker. After electrophoretic separation, PCR products were visualized using a UV transilluminator (Bio-Rad). Positive products were purified and sequenced by Macrogen (Amsterdam, The Netherlands) using NS1 and NS8 universal primers.

Fragment sequences were checked by BLAST search in the GenBank database (http://www.ncbi.nml.nih.gov). An 18S phylogenetic tree was obtained from sequences aligned using the latest SILVA databases for ARB (release 138.1 (Nov 02, 2020) SSURef NR99, http://www.arb-silva.de). The neighbor-joining algorithm and the Jukes-Cantor distance matrix within the ARB package were used to generate the phylogenetic tree based on distance analysis. One thousand bootstrap re-samplings were performed to estimate the robustness of the tree using the same distance model.

\section{3 | Analysis of bacteria associated with dinoflagellates: DNA extraction and bacterial community composition}

In order to analyze the composition of associated bacterial communities in Gambierdiscus australes and Ostreopsis cf. ovata, $10 \mathrm{ml}$ of the cultures of the first strains isolated at Playa Las Canteras-Kraus in September 2015 (CNR GA-LP and CNR OO-LP B1) was harvested by 
centrifugation $(11,000 \times g$ for 5 min. according to Pérez-Guzmán et al., 2008). Total genomic DNA was extracted using MasterPure Complete DNA and RNA Purification Kit (Epicentre) following the manufacturer's instructions. The V3-V4 hypervariable regions of the prokaryotic SSU rRNA gene (Forward =5'TCGTCGGCAGCGTCAGATGTGTATAAGAG ACAGCCTACGGGNGGCWGCAG Reverse =5'GTCTCGTGGG CTCGGAGATGTGTATAAGAGACAGGACTACHVGGGTATCTAATCC, Klindworth et al., 2013) were PCR-amplified, and the amplicons were sequenced on the Illumina MiSeq platform by a commercial company (FISABIO, Valencia, Spain) (http://fisabio.san.gva.es/en/servi cios). Library preparations followed by Illumina sequencing were performed according to standard protocols (Caporaso et al., 2012). Sequences were trimmed to remove barcodes and primers, then those $<150 \mathrm{bp}$, with ambiguous base calls or homopolymer runs exceeding 6 bp were removed. Pre-processed sequences were analyzed by the NGS analysis pipeline of the SILVA rRNA gene database project (SILVAngs 1.3) (Quast et al., 2013). Each sequence was aligned using the SILVA Incremental Aligner (SINA v1.2.10) for ARB SVN (Pruesse et al., 2012) against the SILVA SSU rRNA SEED and quality controlled database (Quast et al., 2013). After quality control, sequences were subject to dereplication on a per sample basis. Identical reads were identified, and the unique reads were clustered (OTUs $98 \%$ similarity) using cd-hit-est (version 3.1.2; http://www.bioinformatics.org/cd-hit) (Li \& Godzik, 2006). The reference read of each OTU was classified by a local nucleotide BLAST search against the non-redundant version of the SILVA SSU Ref dataset (release 132, Dec 13, 2017; http:// www.arb-silva.de) using blastn (version 2.2.30+; http://blast.ncbi. nlm.nih.gov/Blast.cgi) with default settings (Camacho et al., 2009). For the phylogenetic tree, filtered reads and close relatives were initially aligned using the SILVA alignment tool (Pruesse et al., 2007) and manually inserted in ARB (Ludwig et al., 2004). The sequences were aligned using the latest SILVA databases for ARB (release 138.1 (Nov 02, 2020) SSURef NR99, http://www.arb-silva.de). The neighborjoining algorithm and the Jukes-Cantor distance matrix of the ARB package were used to generate the phylogenetic trees based on distance analysis for $16 \mathrm{~S}$ rRNA. One thousand bootstrap re-samplings were performed to estimate the robustness of the tree using the same distance model. The Newick format of the tree was imported in iTOL (https://itol.embl.de/) and edited to obtain the tree shown in Figure 4 See legend for more details.

\section{4 | Statistical analyses}

PAST PAleontological STatistics V3.25 (https://palaeoelectronica. org/2001_1/past/issue1_01.htm) was used to generate the BrayCurtis similarity matrix obtained from the OTU abundance table and calculate diversity index. The same program was used to calculate the contribution of single OTUs to the observed difference between samples (SIMPER test) (Clarke, 1993). The alpha diversity of each microbiome was estimated by using two richness estimators: observed OTUs (Obs) and FisherAlpha $\left(S=a^{*} \ln (1+n / a)\right.$ where $S$ is the number of taxa, $\mathrm{n}$ is the number of individuals and $\mathrm{a}$ is the Fisher's alpha (Fisher et al., 1943), and two diversity indexes: the Shannon $\mathrm{H}$ index

$$
H^{\prime}=-\sum_{i=1}^{R} p_{i} \ln p_{i}
$$

where $p_{i}$ is the proportion of reads belonging to the $i^{\text {th }}$ OTUs in the dataset of interest (Spellerberg \& Fedor, 2003), and the Simpson index:

$$
I=\frac{\sum_{i=1}^{R} n_{i}\left(n_{i}-1\right)}{N(N-1)}
$$

where $n_{i}$ is the number of sequences identified in each OTU of $i^{\text {th }}$ type and $N$ is the total number of sequences in the dataset (Simpson, 1949).

\section{3 | RESULTS}

\subsection{Field samples and dinoflagellate isolates}

Macrophytes collected at the sampling sites were mostly Ochrophyta, such as Halopteris scoparia and Dictyota sp., followed by the Rhodophyta Jania sp. The target species of this study, which are epiphytic on these seaweeds, were i) Gambierdiscus australes, with the typical antero-posteriorly compressed lenticular shape (Figure $2 \mathrm{~A}-\mathrm{C}$ ) and plate formula matching the species descriptions, and ii) Ostreopsis cf. ovata (Figure 2D-F) with the typical tear-drop shape and numerous gold-brown chloroplasts. The morphological identification of these two taxa was confirmed by the results of the molecular analyses showing $99.88 \%$ of identity for G. australes with strain 1080606_3 from Japan (accession number AB764308) and $98.10 \%$ of similarity for O. cf. ovata with strain 1S1D6 from the South China Sea (accession number KX129875) respectively (Figure 3). The two dinoflagellates species were only found in September 2015 at Station 1-Kraus and Station 2-La Cícer of Las Canteras beach, whereas they were not detected at La Puntilla station nor at the other sampling locations southwards along the Gran Canaria coasts. Cell densities at the two stations of Las Canteras ranged between 0 and $100 \mathrm{G}$. australes cells $\mathrm{g}^{-1}$ macroalga (wet weight, ww) and between 0 and 500 O. cf. ovata cells $\mathrm{g}^{-1}$ macroalga (ww). Macroalgae also hosted other dinoflagellates, such as Coolia, Prorocentrum, Amphidinium, and Heterocapsa spp., along with diatoms, mostly Nitzschia, Amphora, and Pleurosigma spp. At the sampling stations, water temperature and salinity were $24.2-24.6^{\circ} \mathrm{C}$ and $36.8-36-9$ in September 2015 and 22.5-23.2 ${ }^{\circ} \mathrm{C}$ and $36.7-36.8$ in October 2016, respectively.

Ostreopsis cf. ovata showed a growth rate of 0.3-0.5 div. day ${ }^{-1}$, which was higher than that of G. australes (0.10-0.17 div. day $\left.{ }^{-1}\right)$.

\section{2 | Phylogenetic characterization of bacteria associated with $\mathrm{G}$. australes and $\mathrm{O}$. cf. ovata}

The bacterial 16S rRNA Illumina sequencing resulted in libraries of 31,473 sequences from O. cf. ovata (OO) and 13,375 from G. australes (GA) cultures. Operational taxonomic units (OTUs) were clustered based on $97 \%$ sequence similarity. Alpha-diversity index 
values were significantly different between the two microbiomes (Table 1). The number of observed taxa (OBS) in OO was more than double that in GA at all taxonomic levels. The highest diversity value was detected at genus level in $\mathrm{OO}$, along with the highest estimated value of the taxa richness (Fisher-a), indicating that rare taxa were also well represented in the sample. The lowest diversity value coupled to the highest dominance expressed as invSimpson index was recorded in GA at phylum level.

Bacterial microbiomes were classified into 8 phyla and 15 classes in $\mathrm{OO}$ and 4 phyla and 7 classes in GA, respectively. The following description of microbial community structure is mainly based on the relative contribution of the major bacterial signatures, that is, those representing more than $1 \%$ in at least one sample. The dominant bacterial phyla in OO were Proteobacteria (49.7\%), Bacteroidetes (24.3\%), and Planctomycetes (14.9\%). The same phyla were detected in GA but with different relative contributions, namely, Proteobacteria (93.3\%), Bacteroidetes (5\%), and Planctomycetes (1\%). Rare phyla $(<1 \%)$ such as Verrucomicrobia, Actinobacteria, TM6, and SHA-109 detected in O. cf. ovata were not recorded in G. australes. Moreover, Cyanobacteria were found only in GA as $0.4 \%$ of the total retrieved taxa (Figure 4, Table 1). At class level, the bacterial microbiome of $\mathrm{OO}$ was dominated by Alphaproteobacteria (40.8\%), whereas the rest of the clades were mainly affiliated to Cytophagia (14\%), Phycisphaerae (12\%), Gammaproteobacteria (6.6\%), Flavobacterilia (6.4\%), Sphingobacteria (4\%), Planctomycetacia (3\%), and Deltaproteobacteria (1.4\%). In GA, the dominance of Alphaproteobacteria was much more marked (83.5\%), whereas the remainder $15.2 \%$ was covered by Gammaproteobacteria (9.2\%), Flavobacteria (5\%), and Phycisphaerae (1\%). At genus level, the $\mathrm{OO}$ microbiome showed the highest diversity values with 21 detected genera. The most abundant clades were affiliated to the Phycispherales clade SM1A02 (11.7\%), Maricaulis (9\%), and Oceanicaulis (5.2\%). Thalassospira were represented by $6.9 \%$ of total OTUs. Moreover, $10.29 \%$ of OTUs were attributable to Cytophagales, mostly including unknown families, among which we were able to identify Fabibacter (1.6\%) and Reichenbachiella (1.3\%). The $3.7 \%$ of the sequences were attributable to Balneola. Two genera were closely related to the family Rhodobacteraceae, namely, Marivita (6.5\%) and Roseovarius (4.7\%). An unclassified NS11-12 marine group belonging to the order Sphingobacteriales constituted $4 \%$ of the total relative abundance. The family Bacteriovoracaceae represented $1.2 \%$ of the total OTUs, which were closely related to genus Peredibacter. OTUs closely related to the genus Methylophaga constituted $1.2 \%$ of the total abundance in OO. Finally, $1.1 \%$ of the OTUs were unclassified genera attributable to the DB1-14 order (Figure 4, Table 2). In GA, 54.5\% of total OTUs were affiliated to Rhodobacteraceae, namely, 42.2\% Labrenzia and 12.3\% Stappia. Hyphomonadaceae covered $19.3 \%$ of the total abundance, with a single genus, Oceanicaulis. Thalassospira constituted $5.9 \%$ of the OTUs representing the family Rhodospirillaceae, together with an uncultured genus (3\%). Marinobacter and Pseudospirillum were 4.5\% and $3.4 \%$ of the total abundance, respectively (Figure 4, Table 2).

A specific focus on the differences between the two microbiomes was applied by means of the SIMPER analysis which revealed a relatively low number of OTUs (14.8\%) shared between O. cf. ovata and G. australes libraries. Remarkably, shared OTUs included almost $50 \%$ of those identified in the GA library. These included four Alphaproteobacteria (Oceanicaulis, Stappia, uncultured Rhodospirillaceae and DB1-14 group) and two Gammaproteobacteria (Marinobacter and Pseudospirillum sp.) (Table 2). Moreover, SIMPER analysis highlighted three OTUs as the major contributors to the difference between the two dinoflagellate microbiomes with an Average dissimilarity (Av. dis) $>5 \%$ : two OTUs belonged to Alphaproteobacteria, namely Labrezia (Av. dis 11.44\%), detected only in GA with $38.35 \%$ of total sequences, and Oceanicaulis (Av. dis $6.8 \%)$, more abundant in GA than OO libraries $(19.19 \%$ and
FIGURE 2 Specimens of Gambierdiscus australes (a-c) and Ostreopsis cf. ovata (d-f) from Las Palmas, Gran Canaria (Spain). Light and epifluorescence micrographs with details of epitheca-Po and apical plates 4' (b), 1' (e)-and hypotheca, with antapical plate $2^{\prime \prime \prime \prime}$ (c) and posterior intercalary plate $1 p(f)$, respectively. Scale bars: $20 \mu \mathrm{m}$ (Gambierdiscus) and $10 \mu \mathrm{m}$ (Ostreopsis)
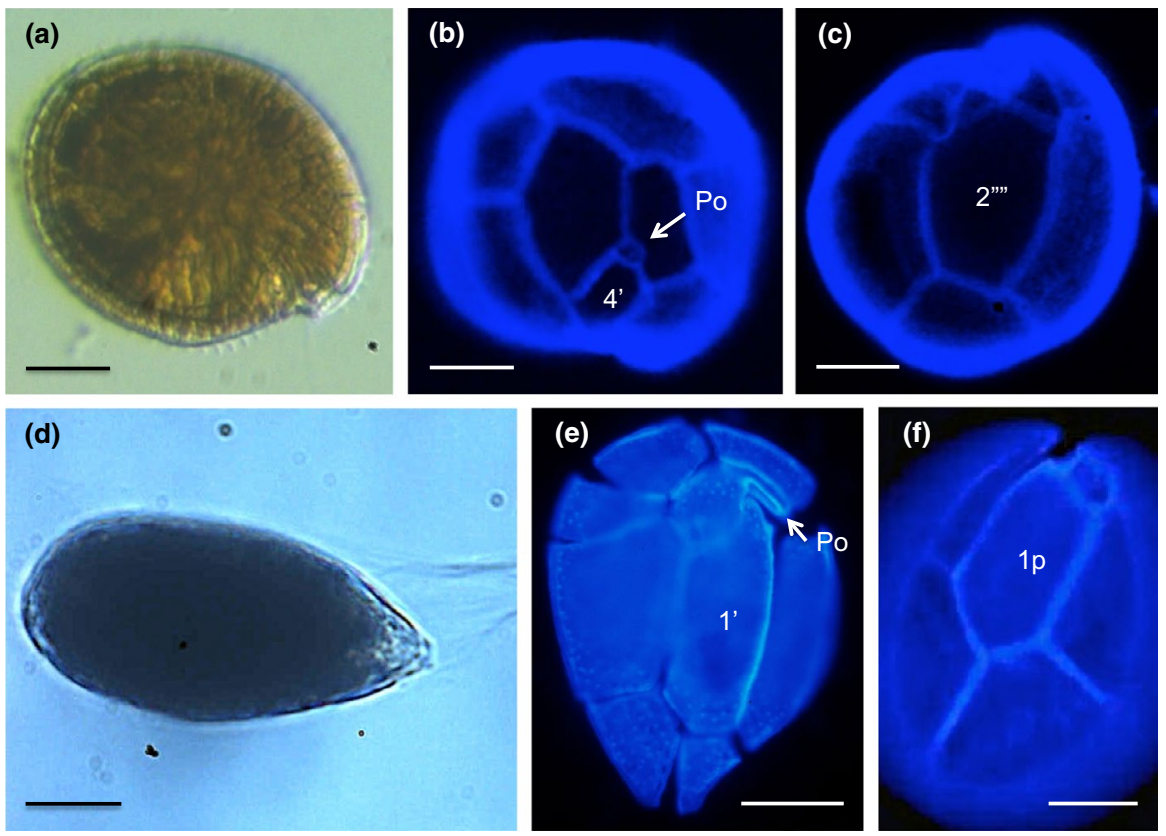
$1.9 \%$ of sequences, respectively). The third OTU belonged to the Plantomycetes SM1A02 (Av. dis 8.2\%), which was detected only in the $O O$ library, where it accounted for $11.73 \%$ of sequences (Table 3 ).

\section{4 | DISCUSSION}

\section{1 | Gambierdiscus and Ostreopsis in Gran Canaria}

In this study, we have focused on the microbiome associated with two different epibenthic species, Gambierdiscus australes and Ostreopsis cf. ovata, based on strains obtained during the same sampling event from a locality of the Atlantic Ocean close to Las Palmas de Gran Canaria, Las Canteras.

In Las Canteras beach, G. australes and O. cf. ovata were isolated from a sample of the ochrophytes Halopteris scoparia and Dictyota sp, the same macrophytes hosting Gambierdiscus spp. in other Canary Islands, such as El Hierro, with the presence there also of Padina pavonica (Soler et al., 2016). Various additional Ochrophyta, Rhodophyta, and Chlorophyta were reported from the Macaronesia region (Canaries and Cape Verde), hosting both Ostreopsis (predominantly) and Gambierdiscus species (Fernández-Zabala et al., 2019). The finding of a single Gambierdiscus species in our samples matches previous observations of $G$. australes as the dominant species of the genus in Gran Canaria, with a minor occurrence of $G$. excentricus (Rodríguez et al., 2017).

The $18 \mathrm{~S}$ rDNA gene analysis supported the morphological identification of the two dinoflagellate species, showing that the Gamberdiscus strain from Las Palmas de Gran Canaria, (Spain) has a high similarity with conspecifics from the Pacific Ocean (Japan, Australia) and other Atlantic areas (Florida). Ostreopsis cf. ovata was placed in a clade with related species from the Pacific Ocean (China and Australia), but with a lower similarity. This result was expected considering the well-known genetic diversity within this species complex (Penna et al., 2010; 2014; Sato et al., 2011) and also because of the absence of reference $18 \mathrm{~s} r D N a$ sequences of $O$. cf. ovata strains from the Atlantic-Mediterranean region, to which presumably our strain belongs. Other studies, based on morphology and/or rDNA sequence data from partial nuclear LSU (D1/D2 domains), 5.8S and non-coding internal transcribed spacer (ITS) regions, have shown 0 . cf. ovata as distributed throughout the Mediterranean Sea as well, whereas G. australes has only recently been found in the Balearic Islands (Zingone et al., 2021, and papers cited therein).

The study of the microbiomes associated with the two dinoflagellates is particularly intriguing because species of these two genera have been implicated in different harmful algal blooms. Among Gambierdiscus species producing lipophilic ciguatoxins and maitotoxins (e.g., Botana, 2014), the species G. australes seems to be less toxic, with a very low to no CTX production (Pisapia et al., 2017). However, G. australes from Canary Islands was described as a CTX producer (Estevez et al., 2020) and a potential MTX-producer (Reverté et al., 2018).

\subsection{Associated microbial communities}

Bacterial diversity observed in the microbiomes was significantly different between the two cultured strains both in terms of biodiversity pattern and OTUs richness, which was considerably higher in Ostreopsis.

The role of the bacteria inhabiting the phycosphere is difficult to define, due to bimodal, synergistic, and/or antagonistic activity they can perform, which can frequently vary under the influence of two main factors: environmental perturbations and/or the state of the host, that is, the growth phase. Moreover, the nature of interchanges between algae and associated bacteria is still object of controversy. An example of different roles played by the microbiomes in our study is provided by SM1A02 (Phycisphaerales), which have frequently been described in macroalgae-associated microbiomes, for example, in Caulerpa sp., as the most abundant microbiome component in specimens affected by disease (Liu et al., 2019). However, SM1A02 were also described as facultative aerobic organisms able to metabolize dimethylsulfoniopropionate, an osmolyte produced by several microalgae including O. cf. ovata (Vanucci et al., 2016), as well as sulfated polysaccharides (Deschaseaux et al., 2018; Rambo et al., 2020). Another example is provided by the Alphaproteobacteria consortium, which was already reported as dominant over all the growth phases of $\mathrm{O}$. cf. ovata cultures, where it mainly included Rhodobacteraceae and Hyphomonadaceae (Guidi et al., 2018). Rhodobacteraceae have been shown to modify their behavior from mutualistic to opportunistic in response to signal molecules, for example, during algal senescence (Guidi et al., 2018; Seyedsayamdost, Carr, et al., 2011; Seyedsayamdost et al., 2011, 2014; Sule \& Belas, 2013).

Among other bacteria identified in our study, Maricaulis (9\% of OTUs in Ostreospsis) were found as growth-promoter ectosymbionts in a hydrocarbon-rich green alga (Denaro et al., 2021; Tanabe et al., 2015); Oceanicaulis, which we detected in both species and were more abundant in Gambierdiscus, were also found in various cultures of other marine microalgae, such as Alexandrium tamarense (Strömpl et al., 2003), Emiliania huxleyi (Zabeti et al., 2010), Eutreptiella sp. (Kuo \& Lin, 2013), and Ostreococcus tauri (Abby et al., 2014). In O. cf. ovata cultures, Oceanicaulis were found to be abundant in different growth phases, and they were associated with the biosynthesis of $B$ vitamins and were proposed as candidates to investigate synergic action with O. cf. ovata during toxic blooms (Guidi et al., 2018). Bacteroidetes, which we retrieved in high abundance in Ostreopsis, possibly have a role in the hydrolysis of biopolymers such as proteins, complex polysaccharides, and glycoproteins (Riedel et al., 2013). In particular, Flavobacteria and Sphingobacteria have been found to be associated with particulate matter/algal detritus contributing to the mineralization processes. In the microbiome associated with G. australes, the most abundant reads ( $>50 \%$ ) were attributed to Labrenzia, which actually were even more abundant considering that the genus Stappia (covering $12.3 \%$ of the library) was recently reclassified as Labrenzia. Previously identified in corals and other microalgal cultures (Chen et al., 2012; Han et al., 2016; Sandhya et al., 2017), 
FIGURE 3 SSU rDNA-based phylogeny of Gambierdiscus australes and Ostreopsis cf. ovata, strains. Sequences obtained in this study are bold-typed in red. Support of nodes is based on bootstrap values of NJ with 1000 re-samplings. Only values greater than 70 are shown. Alexandrium was used as out-group

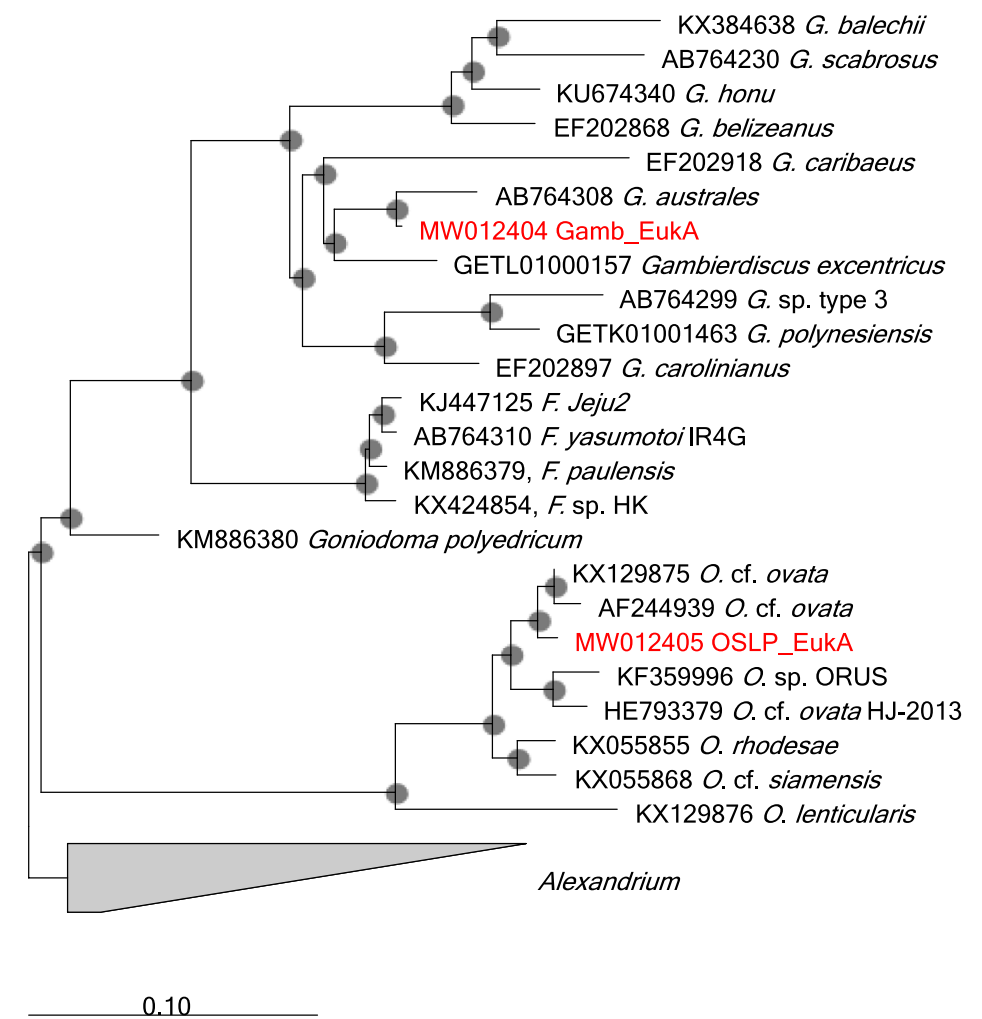

Gambierdiscus

Ostreopsis
TABLE 1 Bacterial alpha diversity in the microbiomes associated with Ostreopsis cf. ovata and Gambierdiscus australes

\begin{tabular}{llllll} 
Rank & Samples & OBS $^{\mathrm{a}}$ & Shannon $^{\mathrm{b}}$ & invSimpson $^{\mathrm{b}}$ & FisherAlpha $^{\mathrm{c}}$ \\
\hline PHYLUM & O. cf. ovata & 8 & 1.28 & 2.96 & 0.75 \\
& G. australes & 4 & 0.29 & 1.15 & 0.38 \\
\multirow{2}{*}{ CLASS } & O. cf. ovata & 15 & 1.88 & 4.52 & 1.51 \\
& G. australes & 7 & 0.63 & 1.41 & 0.71 \\
\multirow{2}{*}{ GENUS } & O. cf. ovata & 68 & 3.14 & 16.67 & 8.24 \\
& G. australes & 32 & 1.89 & 4.17 & 3.94 \\
\hline
\end{tabular}

${ }^{a}$ number of observed taxa (OTU 97\%).

${ }^{\mathrm{b}}$ Lande (1996).

cFisher et al. (1943).
Labrenzia are notable for their ability to produce dimethylsulfoniopropionate (DMSP) (Curson et al., 2017; Salgado et al., 2014), which plays a key role in stress tolerance in dinoflagellates (Sunda et al., 2002; Williams et al., 2019). They have also been described as aerobic anoxygenic photosynthetic bacteria (Biebl et al., 2005, 2007), advantaged under light-dark carbon-limited regime (Koblížek, 2015; Soora et al., 2015; Wang et al., 2015). Labrenzia show a very active metabolic pathway under algal-derived matter remineralization, as during the algal stationary phase (Guidi et al., 2018). However, host-killing, algicidal and antimicrobial activities also seem to be associated with Labrenzia (Amiri Moghaddam et al., 2018; Chen et al., 2017; Fiebig et al., 2013), which could determine their success within the microbiome associated with G. australes and possibly be related to the considerably lower growth performances of the latter compared with O. cf. ovata in our study. An abundance of signatures belonging to Phycisphereae family has recently been highlighted in the microbiome of two Gambierdiscus species, and a possible mutual interaction has been hypothesized based on in silico predictions (Rambo et al., 2020). By contrast, we have detected a relatively high abundance of Phycisphereae family only in O. cf. ovata.

Considering the limitations of the method, the bacterial communities revealed in our study may not reflect entirely the original microbiome and should be considered with caution, because culture conditions over a month may have imposed strong constraints on their composition. However, the quite high diversity of bacterial species found through molecular analyses, along with the profound differences between the microbiomes associated with two species handled in the same way, supports the informative value of our results and allows some general considerations. Because the two dinoflagellates species were isolated from the same location, sampling date, and macroalgal samples, the difference between their microbiomes would point at species-specific associations at least in the environment investigated, supporting the "niche" hypothesis (Hardin, 1960): If one algal species offers defined, stable 
TAB LE 2 List of the identified operational taxonomic units (OTUs) found in libraries from Gambierdiscus australes and Ostreopsis cf. ovata microbiomes

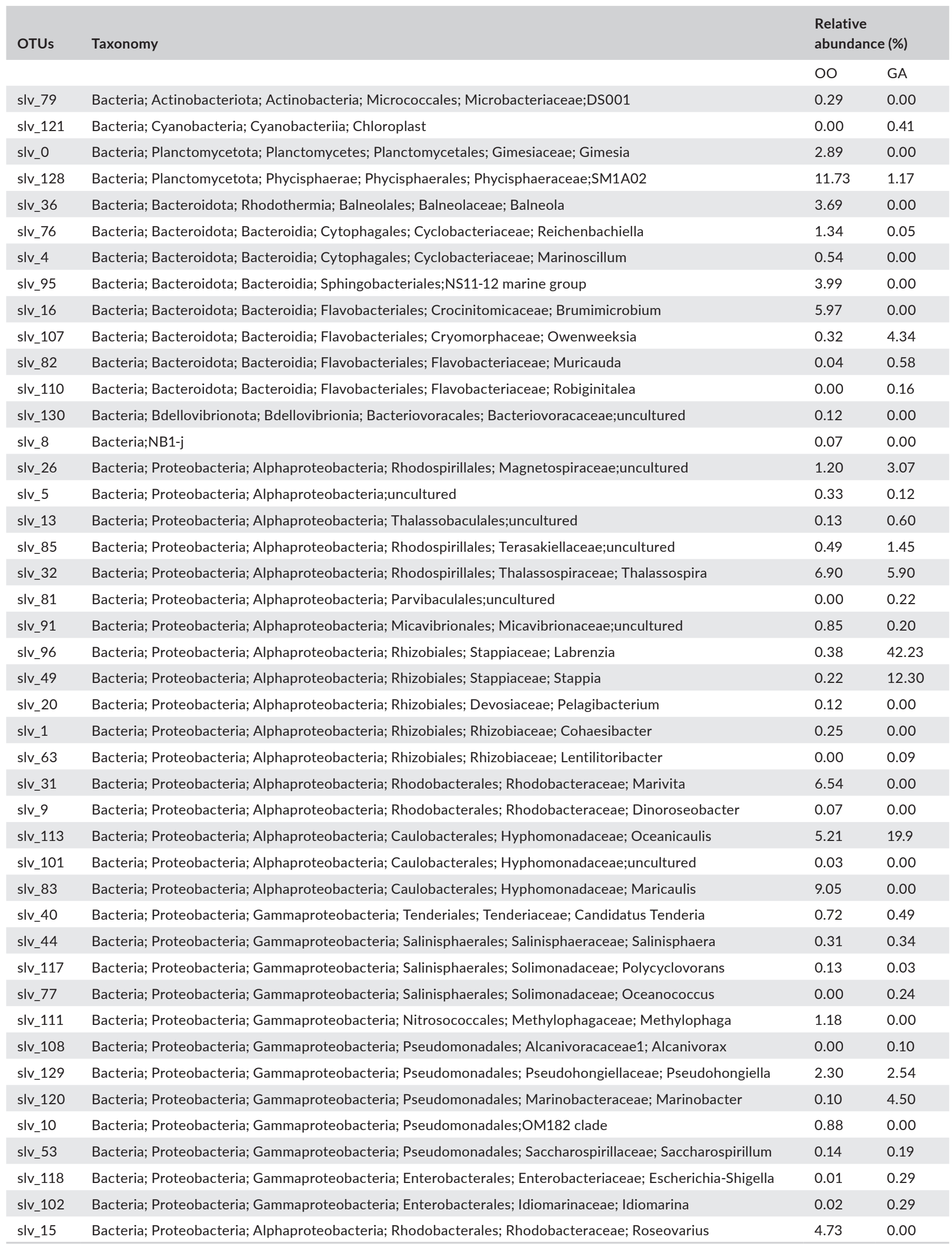




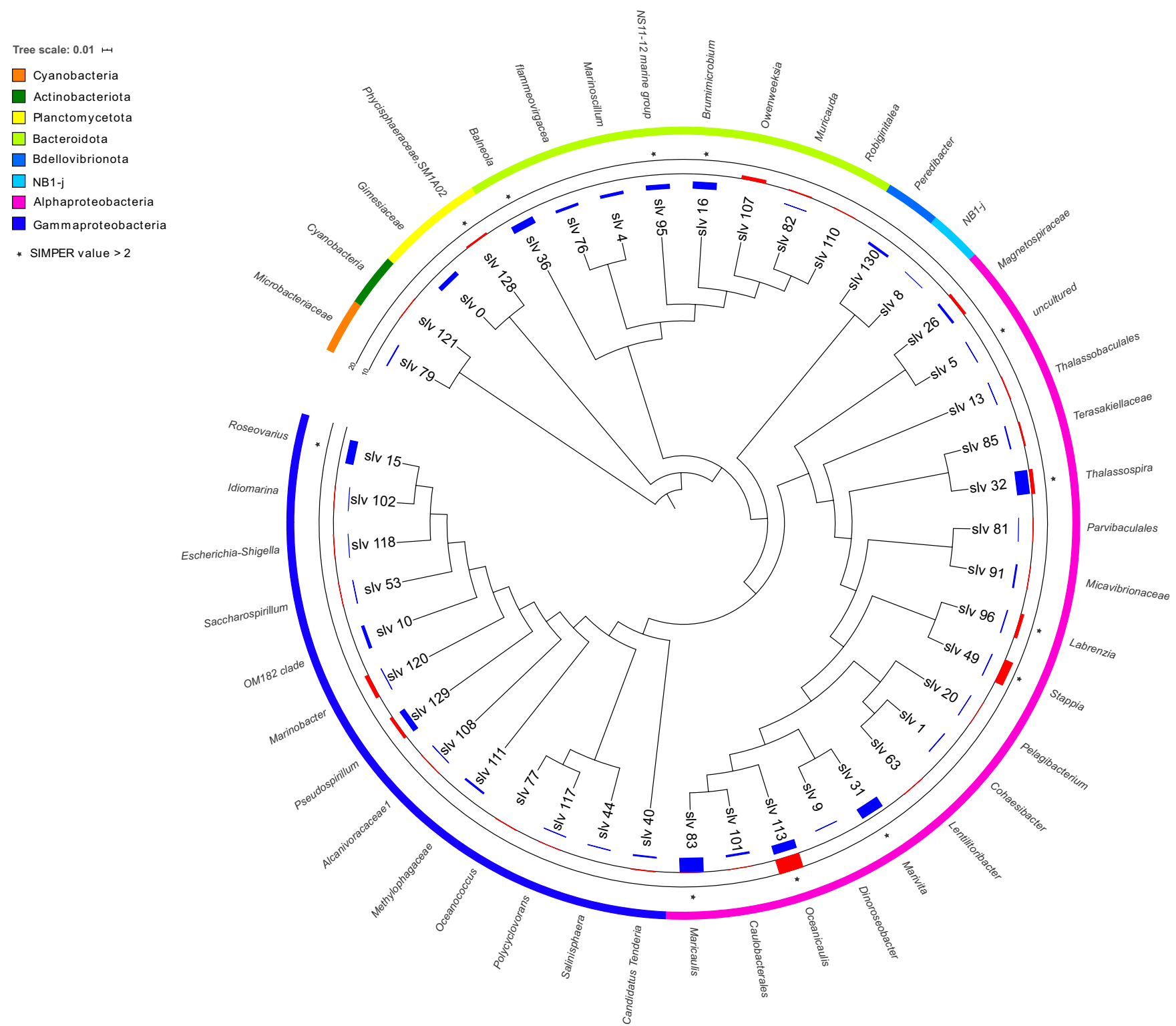

FIG URE 4 Taxonomic composition of the microbiomes associated with Ostreopsis cf. ovata and Gambierdiscus australes based on sequence libraries. Phylogenetic tree was obtained as described in methods; only OTUs with more than 50 reads per OTU are presented. External color circles represent class affiliation, whereas for every OTUs, the most deepest affiliation up to genus level is reported. Stars indicate OTUs with SIMPER value $>2$, red and blue histograms indicate relative abundance of OTUs identified associated in OO and in GA respectively. Figure was edited using iTOL. (https://itol.embl.de/) (Letunic \& Bork, 2019)

conditions, the same well-adapted bacterial species will outcompete the others when present. Species-specific associations of bacteria to algae may depend on various factors such as algal extracellular products, toxicity (Jasti et al., 2005; Schäfer et al., 2002; Šimek et al., 2011) and surface structures and components (Dang \& Lovell, 2002). However, environmental conditions and/or the state of the host could also be responsible for the differences observed. As an example, in Alexandrium catenella a shift of bacterial dominance occurred from Gammaproteobacteria at the initial bloom stage to Alphaproteobacteria during the bloom decline. Therefore, the dominance of Alphaproteobacteria in Ostreopsis and even more in Gambierdiscus could also be related to a difference in the phase of the bloom, which for O. cf. ovata in the western Mediterranean generally occurs in July and declines in late summer-autumn (Mangialajo et al., 2011; Rodríguez et al., 2017).

As discussed above, many of the bacterial taxa have been described associated also with other species of dinoflagellates in addition to Ostreopsis and Gambierdiscus, suggesting a higher relevance of local environmental conditions and/or substrates in determining community patterns of algae-associated microbiomes compared with species-specific interactions (Eigemann et al., 2013). Definitely, further experiments, as well as studies on environmental parameters and seasonal cycles, need to be performed to identify the underlying relationship between dinoflagellates and associated bacteria and to 
TAB LE 3 Similarity percentage analysis (SIMPER) between O. cf. ovata (OO) and G. australes (GA) libraries from their respective associated microbiomes

\begin{tabular}{|lllllll|}
\hline OTU & OO abundance $(\%)$ & $\begin{array}{l}\text { GA abundance } \\
(\%)\end{array}$ & $\begin{array}{l}\text { Mean dissimilarity } \\
(\%)\end{array}$ & Contribution (\%) & Cumulative (\%) & Taxonomic assignment \\
\hline 35 & 0 & 38.35 & 11.44 & 12.33 & 12.33 & Labrenzia \\
\hline 24 & 11.73 & 0 & 8.23 & 8.87 & 21.21 & SM1A02 \\
\hline 38 & 1.93 & 19.19 & 6.79 & 7.32 & 28.54 & Oceanicaulis \\
\hline 91 & 9.7 & 0 & 4.73 & 5.1 & 33.64 & Unc. Alphaproteobacteria \\
\hline 98 & 6.74 & 0 & 4.7 & 5.09 & 38.73 & Maricaulis \\
\hline 95 & 6.73 & 0 & 4.59 & 4.95 & 43.68 & Marivita \\
\hline 108 & 6.5 & 0 & 4.36 & 4.7 & 48.39 & Unc, Hyphomonadaceae \\
\hline 5 & 5.9 & 0 & 4.18 & 4.5 & 52.91 & Brumimicrobium \\
\hline 60 & 5.67 & 0 & 3.9 & 4.2 & 57.2 & Thalassospira \\
\hline 41 & 0.2 & 12.29 & 3.5 & 3.7 & 60.99 & Stappia \\
\hline
\end{tabular}

understand the main drivers for the differences observed in the microbiomes of the two species.

\section{ACKNOWLEDGEMENTS}

Our acknowledgments go to: Dr. Valentina Grasso, UPLGC Las Palmas (Spain), for introducing us to the MIMAR project as an associated participant and help in sample collection and treatment; UPLGC_MIMAR for covering travels to Gran Canaria and subsistence expenses; Dra. Jimena Bravo for the MIMAR course on the CTXs assays at the Marine Science and Technology Park-UPLGC in Taliarte. A special thank goes to Dr. Silvia Casabianca, and Prof. Antonella Penna, University of Urbino-Dept. of Biomolecular Sciences-for their support in the specific identification of Ostreopsis.

\section{CONFLICT OF INTEREST}

The authors declare no conflict of interest.

\section{AUTHOR CONTRIBUTIONS}

Renata Denaro: conceptualization, methodology, validation, investigation, data curation, writing original draft, writing review \& editing. Francesca Crisafi: methodology, investigation, data curation, writing original draft, writing review \& editing. Francesco Smedile: software, validation, formal analysis, investigation, data curation, writing original draft. Vittorio Soprano: writing, review \& editing, visualization. Rachele Rossi: methodology, investigation, data curation, writing original draft. Adriana Zingone: writing review \& editing, visualization. Felix Acosta: writing review \& editing. Maria Grazia Giacobbe: methodology, validation, investigation, writing original draft, writing review \& editing.

\section{DATA AVAILABILITY STATEMENT N/A}

\section{ORCID}

Renata Denaro (D) https://orcid.org/0000-0003-4341-197X

Francesca Crisafi (iD https://orcid.org/0000-0002-4917-893X

\section{REFERENCES}

Abby, S. S., Touchon, M., De Jode, A., Grimsley, N., \& Piganeau, G. (2014). Bacteria in Ostreococcus tauri cultures - friends, foes or hitchhikers? Frontiers in Microbiology, 505, https://doi.org/10.3389/ fmicb.2014.00505

Acosta, F., Herrera, R., Montero, D., Soler-Onís, E., Fernández-Zabala, J., Cruz, R., Santana-Abreu, T., Vega, B., \& Bravo, J. (2018). Monitoring of ciguatoxin carrier fishes in El Hierro island after a toxic dinoflagellate bloom. P.23. XIII Reunión Ibérica de Algas Tóxicas y biotoxinas marinas 2018 Vigo (Spain), 20-22th June 2018

Aligizaki, K., Nikolaidis, G., \& Fraga, S. (2008). Is Gambierdiscus expanding to new areas? Harmful Algae News, 36, 6-7.

Amin, S. A., Hmelo, L. R., van Tol, H. M., Durham, B. P., Carlson, L. T., Heal, K. R., Morales, R. L., Berthiaume, C. T., Parker, M. S., Djunaedi, B., Ingalls, A. E., Parsek, M. R., Moran, M. A., \& Armbrust, E. V. (2015). Interaction and signalling between a cosmopolitan phytoplankton and associated bacteria. Nature, 522, 98-101. https://doi. org/10.1038/nature14488

Amiri Moghaddam, J., Dávila-Céspedes, A., Kehraus, S., Crüsemann, M., Köse, M., Müller, C. E., \& König, G. M. (2018). Cyclopropanecontaining fatty acids from the marine bacterium Labrenzia sp. 011 with antimicrobial and GPR84 activity. Marine Drugs, 16(10), 369. https://doi.org/10.3390/md16100369

Biebl, H., Allgaier, M., Lünsdorf, H., Pukall, R., Tindall, B. J., \& WagnerDöbler, I. (2005). Roseovarius mucosus sp. nov., a member of the Roseobacter clade with trace amounts of bacteriochlorophylla. International Journal of Systematic and Evolutionary Microbiology, 55, 2377-2383. https://doi.org/10.1099/ijs.0.63832-0

Biebl, H., Pukall, R., Lünsdorf, H., Schulz, S., Allgaier, M., Tindall, B. J., \& Wagner-Döbler, I. (2007). Description of Labrenzia alexandrii gen. nov., sp. nov., a novel alphaproteobacterium containing bacteriochlorophylla, and a proposal for reclassification of Stappia aggregata as Labrenzia aggregata comb. nov., of Stappia marina as Labrenzia marina comb. nov. and of Stappia alba as Labrenzia alba comb. nov., and emended descriptions of the genera Pannonibacter, Stappia and Roseibium, and of the species Roseibium denhamense and Roseibium hamelinense. International Journal of Systematic and Evolutionary Microbiology, 57, 1095-1107. https://doi.org/10.1099/ijs.0.64821-0

Botana, L. M. (Ed.) (2014). Seafood and freshwater toxins: pharmacology, physiology, and detection, 3rd ed. Boca Raton.

Bratbak, G., \& Thingstad, T. F. (1985). Phytoplankton-bacteria interactions: an apparent paradox? Analysis of a model system with both competition and commensalism. Marine Ecology Progress Series, 25, 23-30. 
Bravo, J., Suárez, F. C., Ramírez, A. S., \& Acosta, F. (2015). Ciguatera, an emerging human poisoning in Europe. Journal of Aquaculture \& Marine Biology, 3(1), 00053.

Camacho, C., Coulouris, G., Avagyan, V., Ma, N., Papadopoulos, J., Bealer, K., \& Madden, T. L. (2009). BLAST+: architecture and applications. BMC Bioinformatics, 10, 421. https://doi. org/10.1186/1471-2105-10-421

Caporaso, J. G., Lauber, C. L., Walters, W. A., Berg-Lyons, D., Huntley, J., Fierer, N., Owens, S. M., Betley, J., Fraser, L., Bauer, M., Gormley, N., Gilbert, J. A., Smith, G., \& Knight, R. (2012). Ultra-high-throughput microbial community analysis on the Illumina HiSeq and MiSeq platforms. ISME Journal, 6, 1621-1624. https://doi.org/10.1038/ ismej.2012.8

Chen, Y.-H., Kuo, J., Sung, P.-J., Chang, Y.-C., Lu, M.-C., Wong, T.-Y., Liu, J.-K., Weng, C.-F., Twan, W.-H., \& Kuo, F.-W. (2012). Isolation of marine bacteria with antimicrobial activities from cultured and field-collected soft corals. World Journal of Microbiology and Biotechnology, 28, 3269-3279. https://doi.org/10.1007/s1127 4-012-1138-7

Chen, Z., Zheng, W., Yang, L., Boughner, L. A., Tian, Y., Zheng, T., \& Xu, H. (2017). Lytic and Chemotactic Features of the Plaque-Forming Bacterium KD531 on Phaeodactylum tricornutum. Frontiers in Microbiology, 8, 2581. https://doi.org/10.3389/fmicb.2017.02581

Clarke, K. R. (1993). Non-parametric multivariate analyses of changes in community structure. Austral Ecology, 18, 117-143. https://doi. org/10.1111/j.1442-9993.1993.tb00438.x

Cole, J., Findlay, S., \& Pace, M. (1988). Bacterial production in fresh and saltwater ecosystems: A cross-system overview. Marine Ecology Progress Series, 43, 1-10. https://doi.org/10.3354/ meps043001

Croft, M. T., Lawrence, A. D., Raux-Deery, E., Warren, M. J., \& Smith, A. G. (2005). Algae acquire vitamin B12 through a symbiotic relationship with bacteria. Nature, 438, 90-93. https://doi.org/10.1038/ nature 04056

Curson, A. R. J., Liu, J., Bermejo Martínez, A., Green, R. T., Chan, Y., Carrión, O., Williams, B. T., Zhang, S.-H., Yang, G.-P., Bulman Page, P. C., Zhang, X.-H., \& Todd, J. D. (2017). Dimethylsulfoniopropionate biosynthesis in marine bacteria and identification of the key gene in this process. Nature Microbiology, 2, 17009. https://doi. org/10.1038/nmicrobiol.2017.9

Dang, H., \& Lovell, C. R. (2002). Numerical dominance and phylotype diversity of marine Rhodobacter species during early colonization of submerged surfaces in coastal marine waters as determined by $16 \mathrm{~S}$ ribosomal DNA sequence analysis and fluorescence in situ hybridization. Applied and Environmental Microbiology, 68(2), 496-504. https://doi.org/10.1128/AEM.68.2.496-504.2002

Denaro, R., Di Pippo, F., Crisafi, F., \& Rossetti, S. (2021) Biodegradation of Hydrocarbons in Marine Environment. In: A. M. I. Inamuddin, \& E. Lichtfouse (eds) Water Pollution and Remediation: Organic Pollutants. Environmental Chemistry for a Sustainable World, vol 54. Springer, Cham. https://doi.org/10.1007/978-3-030-52395-4_7

Deschaseaux, E., Hardefeldt, J., Jones, G., \& Reichelt-Brushett, A. (2018). High zinc exposure leads to reduced dimethylsulfoniopropionate (DMSP) levels in both the host and endosymbionts of the reefbuilding coral Acropora aspera. Marine Pollution Bulletin, 126, 93100. https://doi.org/10.1016/j.marpolbul.2017.10.070

Eigemann, F., Hilt, S., Salka, I., \& Grossart, H. P. (2013). Bacterial community composition associated with freshwater algae: species specificity vs. dependency on environmental conditions and source community. FEMS Microbiology Ecology, 83(3), 650-663. https://doi. org/10.1111/1574-6941.12022

Estevez, P., Sibat, M., Leão-Martins, J. M., Tudó, A., Rambla-Alegre, M., Aligizaki, K., Diogène, J., Gago-Martinez, A., \& Hess, P. (2020). Use of Mass Spectrometry to Determine the Diversity of Toxins Produced by Gambierdiscus and Fukuyoa Species from Balearic Islands and Crete (Mediterranean Sea) and the Canary Islands (Northeast
Atlantic). Toxins (Basel), 12(5), 305. https://doi.org/10.3390/toxin s12050305

Fernández-Zabala, J., Tuya, F., Amorim, A., \& Soler-Onís, E. (2019). Benthic dinoflagellates: Testing the reliability of the artificial substrate method in the Macaronesian region. Harmful Algae, 87, 101634. https://doi.org/10.1016/j.hal.2019.101634

Fiebig, A., Pradella, S., Petersen, J., Päuker, O., Michael, V., Lünsdorf, H., Göker, M., Klenk, H.-P., \& Wagner-Döbler, I. (2013). Genome of the R-body producing marine alphaproteobacterium Labrenzia alexandrii type strain (DFL-11(T)). Standards in Genomic Sciences, 7, 413426. https://doi.org/10.4056/sigs.3456959

Fisher, R., Corbet, A., \& Williams, C. (1943). The relation between the number of species and the number of individuals in a random sample of an animal population. Journal of Animal Ecology, 12, 42-58. https://doi.org/10.2307/1411

Fritz, L., \& Triemer, R. E. (1985). A rapid simple technique utilizing calcofluor white $\mathrm{m} 2 \mathrm{r}$ for the visualization of dinoflagellate thecal plates 1. Journal of Phycology, 21, 662-664. https://doi. org/10.1111/j.0022-3646.1985.00662.x

Fuentes, J. L., Garbayo, I., Cuaresma, M., Montero, Z., González-DelValle, M., \& Vílchez, C. (2016). Impact of microalgae-bacteria interactions on the production of algal biomass and associated compounds. Marine Drugs, 14(5), 100. https://doi.org/10.3390/md140 50100

García-Altares, M., Casanova, A., Bane, V., Diogène, J., Furey, A., \& de la Iglesia, P. (2014). Confirmation of pinnatoxins and spirolides in shellfish and passive samplers from Catalonia (Spain) by liquid chromatography coupled with triple quadrupole and high-resolution hybrid tandem mass spectrometry. Marine Drugs, 12, 3706-3732. https://doi.org/10.3390/md12063706

Gonzalez, L. E., \& Bashan, Y. (2000). Increased Growth of the Microalga Chlorella vulgaris when Coimmobilized and Cocultured in Alginate Beads with the Plant-Growth-Promoting Bacterium Azospirillum brasilense. Applied and Environmental Microbiology, 66, 1527-1531.

Green, D. H., Llewellyn, L. E., Negri, A. P., Blackburn, S. I., \& Bolch, C. J. S. (2004). Phylogenetic and functional diversity of the cultivable bacterial community associated with the paralytic shellfish poisoning dinoflagellate Gymnodinium catenatum. FEMS Microbiology Ecolology, 47, 345-357. https://doi.org/10.1016/S0168-6496(03)00298-8

Guidi, F., Pezzolesi, L., \& Vanucci, S. (2018). Microbial dynamics during harmful dinoflagellate Ostreopsis cf. ovata growth: Bacterial succession and viral abundance pattern. MicrobiologyOpen, 7, e00584. https://doi.org/10.1002/mbo3.584

Han, J., Zhang, L., Wang, S., Yang, G., Zhao, L., \& Pan, K. (2016). Coculturing bacteria and microalgae in organic carbon containing medium. Journal of Biological Research (Thessaloniki), 23, 8. https://doi. org/10.1186/s40709-016-0047-6

Hardin, G. (1960). The competitive exclusion principle. Science, 131(3409), 1292-1297. https://www.jstor.org/stable/1705965

Jasti, S., Sieracki, M. E., Poulton, N. J., Giewat, M. W., \& Rooney-Varga, J. N. (2005). Phylogenetic diversity and specificity of bacteria closely associated with Alexandrium spp. and other phytoplankton. Applied and Environmental Microbiology, 71, 3483-3494. https://doi. org/10.1128/AEM.71.7.3483-3494.2005

Kaufmann, M., \& Böhm-Beck, M. (2013). Gambierdiscus and related benthic dinoflagellates from Madeira Archipelago (NE Atlantic). Harmful Algae News, 47, 28.

Kim, B.-H., Ramanan, R., Cho, D.-H., Oh, H.-M., \& Kim, H.-S. (2014). Role of Rhizobium, a plant growth promoting bacterium, in enhancing algal biomass through mutualistic interaction. Biomass and Bioenergy, 69, 95-105. https://doi.org/10.1016/j.biombioe.2014.07.015

Klindworth, A., Pruesse, E., Schweer, T., Peplies, J., Quast, C., Horn, M., \& Glöckner, F. O. (2013). Evaluation of general 16 S ribosomal RNA gene PCR primers for classical and next-generation sequencingbased diversity studies. Nucleic Acids Research, 41(1), e1. https:// doi.org/10.1093/nar/gks808 
Koblížek, M. (2015). Ecology of aerobic anoxygenic phototrophs in aquatic environments. FEMS Microbiology Reviewes, 39, 854-870. https://doi.org/10.1093/femsre/fuv032

Kuo, R. C., \& Lin, S. (2013). Ectobiotic and endobiotic bacteria associated with Eutreptiella sp. isolated from Long Island Sound. Protist, 164, 60-74. https://doi.org/10.1016/j.protis.2012.08.004

Lande, R. (1996). Statistics and partitioning of species diversity, and similarity among multiple communities. Oikos, 7, 5-13. https://doi. org $/ 10.2307 / 3545743$

Laza-Martínez, A., David, H., Riobó, P., Miguel, I., \& Orive, E. (2016). Characterization of a Strain of Fukuyoa paulensis (Dinophyceae) from the Western Mediterranean Sea. Journal of Eukaryotic Microbiology, 63, 481-497. https://doi.org/10.1111/jeu.12292

Letunic, I., \& Bork, P. (2019). Interactive tree of life (iTOL) v4: Recent updates and new developments. Nucleic Acids Research, 47, W256-W259. https://doi.org/10.1093/nar/gkz239

Li, W., \& Godzik, A. (2006). Cd-hit: a fast program for clustering and comparing large sets of protein or nucleotide sequences. Bioinformatics, 22, 1658-1659. https://doi.org/10.1093/bioinforma tics/btl158

Liu, J., Zheng, Y., Lin, H., Wang, X., Li, M., Liu, Y., Yu, M., Zhao, M., Pedentchouk, N., Lea-Smith, D., Todd, J., Magill, C., Zhang, W.J., Zhou, S., Song, D., Zhong, H., Xin, Y., Yu, M., Tian, J., \& Zhang, X.-H. (2019). Proliferation of hydrocarbon-degrading microbes at the bottom of the Mariana Trench. Microbiome, 7, 47. https://doi. org/10.1186/s40168-019-0652-3

Ludwig, W., Strunk, O., Westram, R., Richter, L., Meier, H., Yadhukumar Buchner, A., Lai, T., Steppi, S., Jobb, G., Förster, W., Brettske, I., Gerber, S., Ginhart, A. W., Gross, O., Grumann, S., Hermann, S., Jost, R., König, A., Liss, T., ... Schleifer, K.-H. (2004). ARB: A software environment for sequence data. Nucleic Acids Research, 32, 1363-1371. https://doi.org/10.1093/nar/gkh293

Mangialajo, L., Ganzin, N., Accoroni, S., Asnaghi, V., Blanfuneé, A., Cabrini, M., \& Lemé, R. (2011). Trends in Ostreopsis proliferation along the Northern Mediterranean coasts. Toxicon, 57, 408-420. https://doi.org/10.1016/j.toxicon.2010.11.019

Murray, J. S., Nishimura, T., Finch, S. C., Rhodes, L. L., Puddick, J., Harwood, D. T., Larsson, M. E., Doblin, M. A., Leung, P., Yan, M., Rise, F., Wilkinson, A. L., \& Prinsep, M. R. (2020). The role of 44-methylgambierone in ciguatera fish poisoning: Acute toxicity, production by marine microalgae and its potential as a biomarker for Gambierdiscus spp. Harmful Algae, 97, 101853. https://doi. org/10.1016/j.hal.2020.101853

Orr, R. J. S., Stüken, A., Murray, S. A., \& Jakobsen, K. S. (2013). Evolution and distribution of saxitoxin biosynthesis in dinoflagellates. Marine Drugs, 11, 2814-2828. https://doi.org/10.3390/md11082814

Penna, A., Fraga, S., Battocchi, C., Casabianca, S., Giacobbe, M. G., Riobó, P., \& Vernesi, C. (2010). A phylogeographical study of the toxic benthic dinoflagellate genus Ostreopsis Schmidt. Journal of Biogeography, 37, 830-841. https://doi.org/10.1111/j.1365-2699.2009.02265.x

Penna, A., \& Magnani, M. (1999). Identification of Alexandrium (dinophyceae) species using PCR and rDNA-targeted probes. Journal of Phycology, 35, 615-621. https://doi.org/10.1046/ j.1529-8817.1999.3530615.x

Pérez-Guzmán, L., Pérez-Matos, A. E., Rosado, W., Tosteson, T. R., \& Govind, N. S. (2008). Bacteria associated with toxic clonal cultures of the dinoflagellate Ostreopsis lenticularis. Marine Biotechnology, 10, 492-496. https://doi.org/10.1007/s10126-008-9088-7

Pisapia, F., Holland, W. C., Hardison, D. R., Litaker, R. W., Fraga, S., Nishimura, T., Adachi, M., Nguyen-Ngoc, L., Séchet, V., Amzil, Z., Herrenknecht, C., \& Hess, P. (2017). Toxicity screening of 13 Gambierdiscus strains using neuro-2a and erythrocyte lysis bioassays. Harmful Algae, 63, 173-183. https://doi.org/10.1016/j. hal.2017.02.005

Pruesse, E., Peplies, J., \& Glöckner, F. O. (2012). SINA: accurate highthroughput multiple sequence alignment of ribosomal RNA genes.
Bioinformatics, 28, 1823-1829. https://doi.org/10.1093/bioinforma tics/bts 252

Pruesse, E., Quast, C., Knittel, K., Fuchs, B. M., Ludwig, W., Peplies, J., \& Glöckner, F. O. (2007). SILVA: A comprehensive online resource for quality checked and aligned ribosomal RNA sequence data compatible with ARB. Nucleic Acids Research, 35, 7188-7196. https://doi. org/10.1093/nar/gkm864

Quast, C., Pruesse, E., Yilmaz, P., Gerken, J., Schweer, T., Yarza, P., Peplies, J., \& Glöckner, F. O. (2013). The SILVA ribosomal RNA gene database project: Improved data processing and web-based tools. Nucleic Acids Research, 41, D590-596. https://doi.org/10.1093/nar/ gks1219

Rambo, I. M., Dombrowski, N., Constant, L., Erdner, D., \& Baker, B. J. (2020). Metabolic relationships of uncultured bacteria associated with the microalgae Gambierdiscus. Environmental Microbiology, 22, 1764-1783. https://doi.org/10.1111/1462-2920.14878

Reverté, L., Toldrà, A., Andree, K. B., Fraga, S., de Falco, G., Campàs, M., \& Diogène, J. (2018). Assessment of cytotoxicity in ten strains of Gambierdiscus australes from Macaronesian Islands by neuro-2a cell-based assays. Journal of Applied Phycology, 30(4), 2447-2461. https://doi.org/10.1007/s10811-018-1456-8

Riedel, T., Fiebig, A., Petersen, J., Gronow, S., Kyrpides, N. C., Göker, M., $\&$ Klenk, H.-P. (2013). Genome sequence of the Litoreibacter arenae type strain (DSM 19593(T)), a member of the Roseobacter clade isolated from sea sand. Standards in Genomic Sciences, 9, 117-127. https://doi.org/10.4056/sigs.4258318

Rodríguez, F., Fraga, S., Ramilo, I., Rial, P., Figueroa, R. I., Riobó, P., \& Bravo, I. (2017). Canary Islands (NE Atlantic) as a biodiversity "hotspot" of Gambierdiscus: Implications for future trends of ciguatera in the area. Harmful Algae, 67, 131-143. https://doi.org/10.1016/j. hal.2017.06.009

Sachs, J. L., \& Wilcox, T. P. (2006). A shift to parasitism in the jellyfish symbiont Symbiodinium microadriaticum. Proceeding of the Royal Society B: Biological Sciences, 273(1585), 425-429. https://doi. org/10.1098/rspb.2005.3346

Salgado, P., Kiene, R., Wiebe, W., \& Magalhães, C. (2014). Salinity as a regulator of DMSP degradation in Ruegeria pomeroyi DSS-3. Journal of Microbiology, 52, 948-954. https://doi.org/10.1007/s1227 5-014-4409-1

Sandhya, V., Shrivastava, M., Ali, S. Z., \& Sai Shiva Krishna Prasad, V. (2017). Endophytes from maize with plant growth promotion and biocontrol activity under drought stress. Russian Agricultural Sciences, 43, 22-34. https://doi.org/10.3103/S1068367417010165

Sato, S., Nishimura, T., Uehara, K., Sakanari, H., Tawong, W., Hariganeya, N., Smith, K., Rhodes, L., Yasumoto, T., Taira, Y., Suda, S., Yamaguchi, H., \& Adachi, M. (2011). Phylogeography of Ostreopsis along west Pacific coast, with special reference to a novel clade from Japan. PLoS One, 6(12), e27983. https://doi.org/10.1371/journ al.pone. 0027983

Schäfer, H., Abbas, B., Witte, H., \& Muyzer, G. (2002). Genetic diversity of 'satellite' bacteria present in cultures of marine diatoms. FEMS Microbiology Ecology, 42(1), 25-35. https://doi.org/10.1111/ j.1574-6941.2002.tb00992.x

Seyedsayamdost, M. R., Carr, G., Kolter, R., \& Clardy, J. (2011). Roseobacticides: Small molecule modulators of an algal-bacterial symbiosis. Journal of American Chemical Society, 133, 18343-18349. https://doi.org/10.1021/ja207172s

Seyedsayamdost, M. R., Case, R. J., Kolter, R., \& Clardy, J. (2011). The Jekyll-and-Hyde chemistry of Phaeobacter gallaeciensis. Nature Chemistry, 3, 331-335. https://doi.org/10.1038/nchem.1002

Seyedsayamdost, M. R., Wang, R., Kolter, R., \& Clardy, J. (2014). Hybrid biosynthesis of roseobacticides from algal and bacterial precursor molecules. Journal of American Chemical Society, 136, 15150-15153. https://doi.org/10.1021/ja508782y

Šimek, K., Kasalický, V., Zapomělová, E., \& Horňák, K. (2011). Algaderived substrates select for distinct betaproteobacterial lineages 
and contribute to niche separation in Limnohabitans strains. Applied and Environmental Microbiology, 77(20), 7307-7315. https:// doi.org/10.1128/AEM.05107-11

Simpson, E. (1949). Measurement of diversity. Nature, 163, 688. https:// doi.org/10.1038/163688a0

Soler, O. E., Fernández-Zabala, J., Ojeda-Rodríguez, A., \& Amorin, A. (2016). Bloom of Gambierdiscus caribaeus in the temperatesubtropical waters of El Hierro, Canary Islands (North East Atlantic). Harmful Algae News, 55, 14-17.

Soora, M., Tomasch, J., Wang, H., Michael, V., Petersen, J., Engelen, B., Wagner-Döbler, I., \& Cypionka, H. (2015). Oxidative stress and starvation in Dinoroseobacter shibae: the role of extrachromosomal elements. Frontiers in Microbiology, 6, 233. https://doi.org/10.3389/ fmicb.2015.00233

Spellerberg, I. F., \& Fedor, P. J. (2003). A tribute to Claude Shannon (1916-2001) and a plea for more rigorous use of species richness, species diversity and the 'Shannon-Wiener' index. Global Ecology Biogeography, 12, 177-179. https://doi. org/10.1046/j.1466-822X.2003.00015.x

Strömpl, C., Hold, G. L., Lünsdorf, H., Graham, J., Gallacher, S., Abraham, W. R., Moore, E. R. B., \& Timmis, K. N. (2003). Oceanicaulis alexandrii gen. nov., sp. nov., a novel stalked bacterium isolated from a culture of the dinoflagellate Alexandrium tamarense (Lebour) Balech. International Journal of Systematic and Evolutionary Microbiology, 53(Pt 6), 1901-1906. https://doi.org/10.1099/ijs.0.02635-0

Sule, P., \& Belas, R. (2013). A novel inducer of Roseobacter motility is also a disruptor of algal symbiosis. Journal of Bacteriology, 195, 637-646. https://doi.org/10.1128/JB.01777-12

Sunda, W., Kieber, D. J., Kiene, R. P., \& Huntsman, S. (2002). An antioxidant function for DMSP and DMS in marine algae. Nature, 418 , 317-320. https://doi.org/10.1038/nature00851

Tanabe, Y., Okazaki, Y., Yoshida, M., Matsuura, H., Kai, A., Shiratori, T., Ishida, K., Nakano, S., \& Watanabe, M. M. (2015). A novel alphaproteobacterial ectosymbiont promotes the growth of the hydrocarbon-rich green alga Botryococcus braunii. Scientific Report, 5, 10467. https://doi.org/10.1038/srep10467

Tibiriçá, C. E. J. A., Leite, I. P., Batista, T. V. V., Fernandes, L. F., Chomérat, N., Herve, F., Hess, P., \& Mafra, L. L. (2019). Ostreopsis cf. ovata Bloom in Currais, Brazil: Phylogeny, Toxin Profile and Contamination of Mussels and Marine Plastic Litter. Toxins (Basel), 11, 446. https:// doi.org/10.3390/toxins11080446

Tosteson, T. R., Ballantine, D. L., Tosteson, C. G., Hensley, V., \& Bardales, A. T. (1989). Associated bacterial flora, growth, and toxicity of cultured benthic dinoflagellates Ostreopsis lenticularis and Gambierdiscus toxicus. Applied and Environmental Microbiology, 55, 137-141. https://doi.org/10.1128/AEM.55.1.137-141.1989

Tudò, A., Gaiani, G., Varela, M. R., Tsumuraya, T., Andree, K. B., FernándezTejedor, M., Campàs, M., \& Diogène, J. (2020). Further advance of Gambierdiscus species in the Canary islands, with the first report of Gambierdiscus belizeanus. Toxins (Basel), 12(11), 692. https://doi. org/10.3390/toxins12110692
Vanucci, S., Guidi, F., Pistocchi, R., \& Long, R. A. (2016). Phylogenetic structure of bacterial assemblages co-occurring with Ostreopsis cf. ovata bloom. Harmful Algae, 55, 259-271. https://doi.org/10.1016/j. hal.2016.04.003

Wang, B., Yao, M., Zhou, J., Tan, S., Jin, H., Zhang, F., Mak, Y. L., Wu, J., Lai Chan, L., \& Cai, Z. (2018). Growth and Toxin Production of Gambierdiscus spp. Can Be Regulated by Quorum-Sensing Bacteria. Toxins (Basel), 10, 257. https://doi.org/10.3390/toxins10070257

Wang, D.-Z. (2008). Neurotoxins from marine dinoflagellates: a brief review. Marine Drugs, 6, 349-371. https://doi.org/10.3390/md200 80016

Wang, Z., Leary, D. H., Malanoski, A. P., Li, R. W., Hervey, W. J., Eddie, B. J., Tender, G. S., Yanosky, S. G., Vora, G. J., Tender, L. M., Lin, B., \& Strycharz-Glaven, S. M. (2015). A previously uncharacterized, nonphotosynthetic member of the Chromatiaceae is the primary CO2fixing constituent in a self-regenerating biocathode. Applied and Environmental Microbiology, 81, 699-712. https://doi.org/10.1128/ AEM.02947-14

White, T. J., Bruns, T., Lee, S. J. W. T., \& Taylor, J. (1990). Amplification and direct sequencing of fungal ribosomal RNA genes for phylogenetics. PCR Protocols: a Guide to Methods and Applications, 18(1), 315-322.

Williams, B. T., Cowles, K., Bermejo Martínez, A., Curson, A. R. J., Zheng, Y., Liu, J., Newton-Payne, S., Hind, A. J., Li, C.-Y., Rivera, P. P. L., Carrión, O., Liu, J. I., Spurgin, L. G., Brearley, C. A., Mackenzie, B. W., Pinchbeck, B. J., Peng, M., Pratscher, J., Zhang, X.-H., ... Todd, J. D. (2019). Bacteria are important dimethylsulfoniopropionate producers in coastal sediments. Nature Microbiology, 4, 1815-1825. https://doi.org/10.1038/s41564-019-0527-1

Zabeti, N., Bonin, P., Volkman, J. K., Guasco, S., \& Rontani, J.-F. (2010). Fatty acid composition of bacterial strains associated with living cells of the haptophyte Emiliania huxleyi. Organic Geochemistry, 41, 627-636. https://doi.org/10.1016/j.orggeochem.2010.04.009

Zingone, A., Escalera, L., Aligizaki, K., Fernández-Tejedor, M., Ismael, A., Montresor, M., Mozetič, P., Taş, S., \& Totti, C. (2021). Toxic marine microalgae and noxious blooms in the Mediterranean Sea: A contribution to the Global HAB Status Report. Harmful Algae, 102, 101843. https://doi.org/10.1016/j.hal.2020.101843

How to cite this article: Denaro, R., Crisafi, F., Smedile, F., Soprano, V., Rossi, R., Zingone, A., Acosta, F., \& Giacobbe, M. G. (2022). Microbiomes associated with cultures of Gambierdiscus australes and Ostreopsis cf. ovata, two epibenthic dinoflagellates from the NE Atlantic Ocean (Las Palmas, Gran Canaria). Marine Ecology, 00e1-13. https://doi. org/10.1111/maec.12699 